\title{
Stomatal conductance and xylem-sap abscisic acid (ABA) in adult oak trees during a gradually imposed drought
}

\author{
MB Triboulot 1,2, ML Fauveau 1,2, N Bréda 1, \\ $P$ Label $^{2}$, E Dreyer ${ }^{1 *}$ \\ ${ }^{1}$ Équipe bioclimatologie et écophysiologie, unité d'écophysiologie forestière, Centre de Nancy, \\ Inra, 54280 Champenoux; \\ 2 Unité physiologie du développement, laboratoire d'amélioration des arbres forestiers, \\ Centre d'Orléans, Inra, 45160 Olivet, France
}

(Received 18 October 1994; accepted 19 June 1995)

\begin{abstract}
Summary - Thirty- to 40-year-old oak trees (Quercus petraea Matt Liebl and $Q$ robur L) growing in a forest stand near Champenoux (Nancy, France) were submitted to an imposed drought in a lysimeter during two successive summers. Xylem sap was extracted from leafy twigs of two trees per species at regular intervals during the onset of drought, and of two controls in parallel. Predawn leaf water potential, soil water potential at different depths and midday stomatal conductance of sun-exposed leaves were recorded at the same pace. Concentrations of abscisic acid (ABA) and of the glucose ester of $A B A$ (ABA-GE) were measured with an ELISA technique, after purification of the sap samples using high performance liquid chromatography (HPLC). Mean concentrations of ABA recorded in the absence of drought constraint were around $30 \mu \mathrm{mol} \mathrm{m} \mathrm{m}^{-3}$, independently from year and species, and $45 \mu \mathrm{mol} \mathrm{m} \mathrm{m}^{-3}$ for ABA-GE. No significant drought-related increase in either of these concentrations could be recorded while predawn leaf water potential dropped below $-1.5 \mathrm{MPa}$, and stomatal conductance down to $10 \%$ of the values of controls. A good correlation between stomatal conductance and predawn leaf water potential was detected, and even a better one between stomatal conductance and soil water potential at $25 \mathrm{~cm}$. It may be concluded from these results that, even if a close correlation exists between stomatal aperture and soil moisture, the existence of a root signalling process based solely on increased $A B A$
\end{abstract}

* Correspondence and reprints: dreyer@nancy.inra.for

Abbreviations: ABA: abscisic acid; ABA-GE: glucose ester of abscisic acid; MeABA: methyl ester of $A B A ; A B A_{x y l}$ and $A B A-G E_{x y \mid}:$ concentrations of, respectively, $A B A$ and $A B A-G E$ in the xylem sap $\left(\mu \mathrm{mol} \mathrm{m} \mathrm{m}^{-3}\right) ; \mathrm{Q}_{\text {ext }}$ : volume of xylem sap extracted from the twigs $(\mu \mathrm{L}) ; \mathrm{BSA}$ : bovine serum albumin; ELISA: enzyme-linked immunosorbent assay; $g_{s}$ : stomatal conductance $\left(\mathrm{mmol} \mathrm{m}^{-2} \mathrm{~s}^{-1}\right)$; $\Psi_{w p}$ : predawn leaf water potential (MPa). 
or ABA-GE transport in the xylem sap may be questioned. Stomatal conductance under natural conditions is probably controlled by a rather complex chain of processes which has still to be elucidated.

\author{
ABA / ABA-GE / drought / stomatal conductance / water stress / xylem sap / Quercus robur / Quer- \\ cus petraea
}

Résumé - Conductance stomatique et acide abscissique dans la sève brute de chênes adultes au cours d'une sécheresse. Des chênes âgés de 30 à 40 ans appartenant aux deux espèces pédonculé et sessile (Quercus robur $L$ et $Q$ petraea Matt Liebl) ont été sélectionnés dans un haut perchis de la forêt domaniale de Champenoux (Nancy, France), et soumis à une sécheresse contrôlée dans une cuve lysimétrique au cours de deux étés successifs. De la sève brute a été extraite du xylème de rameaux feuillés à intervalles de temps réguliers pendant l'installation de la sécheresse, et sur des arbres témoins. Le potentiel hydrique de base, le potentiel hydrique du sol à différentes profondeurs et la conductance stomatique en milieu de journée ont été relevés sur les mêmes arbres. Les concentrations en acide abscissique ( $A B A)$ et en glucose-ester d'ABA ( $A B A-G E)$ ont été déterminées dans ces échantillons de sève à l'aide d'un dosage Elisa, après purification par HPLC. En l'absence de sécheresse, les concentrations moyennes en $A B A$ étaient de l'ordre de $30 \mu \mathrm{mol} \mathrm{m} \mathrm{m}^{-3}$, et de $45 \mu \mathrm{mol} \mathrm{m} \mathrm{m}^{-3}$ pour l'ABA-GE. Ces concentrations étaient indépendantes de l'espèce et de l'année de mesure; seules les concentrations en ABA-GE ont fortement augmenté d'une année sur l'autre. Aucune augmentation significative due à la sécheresse n'a pu être détectée, bien que les potentiels hydriques de base aient chuté jusqu'à des valeurs inférieures à $-1,5 \mathrm{MPa}$, et que la conductance stomatique ait été réduite à $10 \%$ des valeurs initiales dans certains cas. Une bonne corrélation entre conductance stomatique et potentiel hydrique de base a pu être mise en évidence. Cette corrélation a été améliorée en utilisant les valeurs de potentiel hydrique de sol à $25 \mathrm{~cm}$ de profondeur. Nous concluons que, même si une bonne corrélation existe entre conductance stomatique et humidité du sol, l'existence d'un signal racinaire sous la forme exclusive d'un transport d'ABA ou d'ABA-GE des racines vers les couronnes est peu probable. La conductance stomatique de chênes de grande taille poussant en conditions naturelles est vraisemblablement contrôlée par un processus complexe qui reste à préciser.

$A B A$ / ABA-GE / sécheresse / conductance stomatique / stress hydrique / sève brute / Quercus robur / Quercus petraea

\section{INTRODUCTION}

Oak trees frequently suffer from droughtinduced dieback (Landmann et al, 1993). Intensive studies on water relations of 30year-old oak trees in a stand near Nancy, France, have shown that the two European species (Quercus robur $L$ and $Q$ petraea Matt Liebl) were rather drought tolerant, due to a deep and efficient rooting system (Bréda et al, 1995b), associated with a low sensitivity to cavitation in the xylem conduits (Cochard et al, 1992), and the maintenance of substantial transpiration rates and open stomata till rather low soil moisture (Bréda et al, 1993a,b; Epron and Dreyer, 1993). The question therefore arose of the factors controlling stomatal opening in these trees, and whether root-issued abscisic acid (ABA) was involved in this control.

Much accumulated evidence suggests that stomatal closure during drought may be triggered by a nonhydraulic signal originating from the roots exposed to drying soils (see reviews by Davies and Zhang, 1991; and Davies et al, 1994). ABA is the most frequently suggested chemical effector thought to be released from drying roots, and transported via the transpiration stream in the xylem to the apoplastic spaces in the leaves where it interacts with the guard cells and induces stomatal closure (Davies et al, 1994). Actually, ABA concentrations in xylem and in apoplastic sap have been shown to increase with soil water depletion 
in many plant species including trees (Scuiller, 1990; Wartinger et al, 1990; Hartung and Slovik, 1991; Khalil and Grace, 1993), and to correlate rather well with stomatal conductance in many cases (Tardieu and Davies, 1992; Khalil and Grace, 1993; Correia and Pereira, 1994). Nevertheless, the relationship was very diverse, leading to the assumption that the stomatal sensitivity to xylem ABA could vary among species, and in a given species in relation to other physiological parameters, such as leaf water status (Tardieu and Davies, 1992) or chemical composition of the xylem sap (Schurr et al, 1992).

Despite this evidence, there is still some discussion about the quantitative implication of root-issued ABA in the control of stomatal conductance. In particular, data obtained on adult trees, where a long distance transport of root-issued ABA is required, are still scarce (Wartinger et al, 1990). Moreover, most ABA data have been obtained from unpurified sap samples with an ELISA test, which does not accurately detect combined $A B A$ such as the glucose ester (ABA-GE) that might play an important role as a transport form. To test if drought promoted significant increases in the concentrations of both forms of $A B A$ in relation to stomatal closure, we collected xylem sap during two successive summers (1992 and 1993) on oak trees in an experimental field plot submitted to a gradual soil water depletion, and quantitated ABA using high performance liquid chromatography (HPLC) purification and ELISA detection (Label et al, 1994). It has often been argued that root signalling could allow an adequate stomatal response to the desiccation of the upper soil levels where rooting is dense while deeper layers remain humid (Davies and Zhang, 1991). To verify this hypothesis, we tested for correlations between soil water potential at several depths in the soil and stomatal conductance of sun-exposed leaves.

\section{MATERIALS AND METHODS}

\section{Experimental design}

The experiment was conducted during the summers of 1992 and 1993 in an oak forest at Champenoux near Nancy, northeastern France, on 30year-old and approximatively $18 \mathrm{~m}$ high trees. Four dominant trees (two Quercus robur and two Quercus petraea) were selected in a group of 17 trees included in a water-stressed plot. An artificial drought was applied: rain and throughfall were prevented by a plastic roof built under the canopy and lateral drainage was removed in $1 \mathrm{~m}$ deep trenches. The roof was installed before bud-break, at the end of February 1992, and trees depleted gradually the extractable soil water. During 1992 , a heavy thunderstorm promoted an uncontrolled rewatering on d266. Four other trees were chosen as controls. They were watered manually during the measurement period in 1992, and experienced natural water balance during 1993. During 1993, sap collection was restricted to two stressed and two control trees of $Q$ petraea. For additional details about the experimental design, see Bréda et al (1993a). Climate was recorded with a weather station installed above the canopy, yielding global radiation, air temperature, wind speed and vapour pressure deficits at a half-hourly pace. Stomatal conductance $\left(g_{\mathrm{s}}\right)$ was recorded with a steady-state porometer (LI-1600, LI-Cor, Lincoln, NE, USA) during bright sunny days. Measurements were made between 12 and 14 PM UT on ten sun-exposed leaves of the upper canopy of each tree. Predawn leaf water potential ( $\Psi_{\text {wp }}$, two replicates per tree) was measured on the same days with a Scholander pressure chamber. Soil water potential at 25, 50, 80, 110 and $140 \mathrm{~cm}$ depth was recorded with soil psychrometers (Wescor HR 33T). To avoid artefacts due to uncontrolled soil rehydration, we restricted the analysis of the relationships between soil water and stomatal conductance to trees grown in the lysimeter, and to the period of onset of drought (Q petraea and Q robur, 1992 and 1993).

\section{Extraction of xylem sap}

Immediately after the measurements of stomatal conductance, one extraction was made per tree (two per treatment). A 20 to $30 \mathrm{~cm}$ long twig with 
four to ten leaves was cut of the upper crown and rapidly enclosed into a Scholander pressure chamber. The bark was removed from the distal end to avoid pollution of xylem sap by ABA exuding from phloem tissues (Else et al, 1994). Fifty to $400 \mu \mathrm{L}$ (measured by differential weighing of the vials before and after collection) were sampled by pressurising the twigs at about $0.5 \mathrm{MPa}$ above the balancing pressure. The sap was absorbed directly from exuding vessels with a micropipette: sap droplets were absorbed as soon as they appeared to minimize evaporation. The samples were immediately deep-frozen in liquid nitrogen and stored at $-20^{\circ} \mathrm{C}$ for later analysis.

\section{Purification of xylem sap}

Tritiated ABA (2.26 Bq mol-1, Amersham) was added as an internal standard after sample thawing. The sap was filtered through a $0.22 \mathrm{~mm}$ filter and purified with reverse phase C18 SepPack cartridges before injection onto an HPLC column (Lichrospher 100 RP18, $250 \times 5 \mathrm{~mm}, 5 \mathrm{~mm}$, Merck during 1992, and a Lichrospher 100-5C18, $250 \times 8 \mathrm{~mm}, 4.6 \mu \mathrm{m}$, during 1993). This solid phase was eluted with an $\mathrm{H}_{2} \mathrm{O}$-acetonitrile gradient, that allowed separation of ABA-GE from ABA. Fractions ( $0.15 \mathrm{~min}$ each) were collected between 8.75 and $10.25 \mathrm{~min}$, which interval included retention times of $A B A$ and $A B A-G E$. The ten fractions ( $160 \mu \mathrm{L}$ each) were evaporated to dryness and methylated with diazomethane dissolved in diethylether. After the methylation step, fractions were evaporated to dryness a second time and redissolved in $1 \mathrm{~mL}$ of an aqueous phase with $200 \mathrm{mg} / \mathrm{L} \mathrm{NaN}_{3}$. The incubation before immunoassay was longer than $12 \mathrm{~h}$.

The radioactivity was determined in an aliquot of each sample with a liquid scintillation counter (Beckman LS 1801). Recovery was in all cases higher than $60 \%$. For each sample the recovery efficiencies for ABA-GE and ABA were considered to be identical and used to correct the measured $A B A$ and $A B A-G E$ levels.

\section{Measurement of Me-ABA and ABA-GE}

Quantification of methylated $A B A(M e-A B A)$ and of $A B A-G E$ was established with an enzymelinked immunosorbent assay (ELISA). Plate wells were coated with $200 \mu \mathrm{L}$ of an Ovalbumin com- plex in each well, and plates were incubated overnight at room temperature. The emptied plates were washed four times with $400 \mu \mathrm{L}$ of a washing solution (Photoflo $0.1 \%$ ). Fifty $\mu \mathrm{L}$ of a saturated PBS-gelatine buffer were added to each well followed by $100 \mu \mathrm{L}$ of either Me-ABA standard or sample. Four standard ranges were set on each plate. The first column was used to determine maximal colouration (absence of Me-ABA) and the last one to determine nonspecific colouration (no Me-ABA nor anti-ABA antibody). Two replicates of each sample were used. Then, $50 \mu \mathrm{L}$ of the rabbit anti-ABA IgG were added to each well except those of the last column. The dilution of the antibody corresponded to $50 \%$ of maximum binding to wells. The plates were stirred for $1 \mathrm{~min}$, capped and stored at $+4^{\circ} \mathrm{C}$ for $2 \mathrm{~h}$. After the competition step, plates were washed again and each well was filled with $200 \mu \mathrm{L}$ of the biotinylated goat antirabbit lgG. After 1 min gentle stirring, the plates were incubated $1 \mathrm{~h}$ at $+40^{\circ} \mathrm{C}$. Wells were washed another time and $200 \mu \mathrm{L}$ of the streptavidine-alkaline-phosphatase complex added. The plates were stirred, and incubation carried out at $+40^{\circ} \mathrm{C}$ for $1 \mathrm{~h}$. They were washed again and $200 \mathrm{~mL}$ of $p$-nitrophenyl phosphate added. The reaction proceeded at $+40^{\circ} \mathrm{C}$ during 1-2 $\mathrm{h}$ until maximal absorbance reached 1 AU. The reading of plates was taken at 405 and $610 \mathrm{~nm}$ with a double wavelength spectrophotometer (Dynatech MR 5000). The relative absorbance $\left(B-B_{0}\right) /\left(B_{\max }-B_{0}\right)$ was plotted against the $\log$ of Me-ABA concentration. The quantity of Me-ABA in samples was determined on the basis of calibration curves for each plate. This technique had been validated by Label et al (1994) with poplars.

Purification of xylem sap separated $A B A$ from ABA-GE. The rabbit anti-ABA IgG shows crossreactivity with $A B A-G E$, which concentration was therefore determined with the same procedure, except that calibration curves used ABA-GE. ABA-GE measurements were made only for $Q$ petraea.

\section{RESULTS}

\section{Leaf water potential and stomatal conductance}

Drought induced an important decline of predawn leaf water potential $\left(\Psi_{w p}\right)$ during 


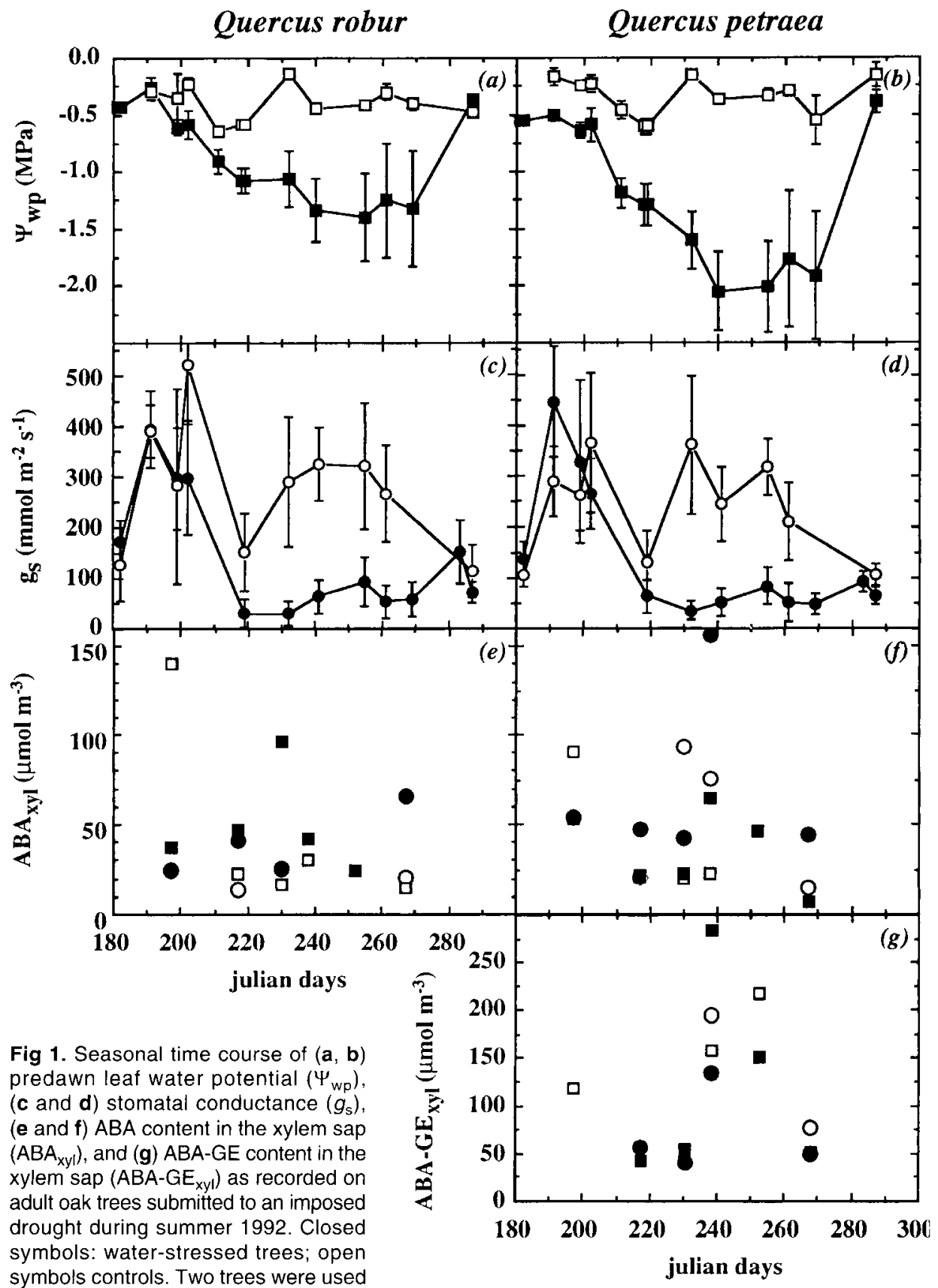

in each species (Quercus robur and $Q$ petraea) and treatment. Mean \pm standard deviation. 
1992. $\Psi_{\text {wp }}$ was lower in stressed trees than in controls during the period between $\mathrm{d} 210$ and d270 (fig 1a, b). It dropped below -1.5 and $-2 \mathrm{MPa}$ in $Q$ robur and $Q$ petraea, respectively, and remained above $-0.8 \mathrm{MPa}$ in controls. At the end of the summer, rewatering due to heavy thunderstorms occurred in the dry plot (d270) and $\Psi_{w p}$ of stressed trees recovered levels of controls. During the second year, a wet spring followed by a dry summer resulted in parallel decreases of $\Psi_{\text {wp }}$ in both treated and controls down to $-1.5 \mathrm{MPa}$ (fig 2a). Stomatal conductance $\left(g_{\mathrm{s}}\right)$ of control trees stabilised at $250 \mathrm{mmol}$ $\mathrm{m}^{-2} \mathrm{~s}^{-1}$ in both species during 1992, after a spring peak value which was related to leaf maturation (fig 1c, d). During autumn, it decreased to $100 \mathrm{mmol} \mathrm{m}^{-2} \mathrm{~s}^{-1}$. Drought induced stomatal closure, with low conduc-

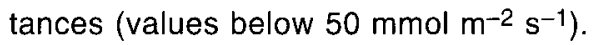
During 1993, both stressed and control trees displayed a similar time course of $g_{\mathrm{s}}$ with a low and gradual decrease to $100 \mathrm{mmol} \mathrm{m}^{-2}$ $\mathrm{s}^{-1}$ (fig $2 \mathrm{~b}$ ). The relationship between drought intensity (expressed by $\Psi_{w p}$ ) and $g_{\mathrm{s}}$ is shown in figure $5(\mathrm{a}, \mathrm{b})$. It was not linear, as has been frequently observed in oaks (Bréda et al, 1993a; Epron and Dreyer, 1993): a steep decline of $g_{\mathrm{s}}$ at high $\Psi_{w p}$ was followed by a much slower one at lower $\Psi_{\text {wp }}$ (below-1.0 MPa). The 1993 data differed in this respect, as they displayed much higher values of $g_{\mathrm{s}}$ at $\Psi_{\mathrm{wp}}$, around -1 to $-1.5 \mathrm{MPa}$. This was probably an effect of the lower vapour pressure deficits during these measurements (around 14.5 versus $21.5 \mathrm{~Pa}$ $\mathrm{kPa}^{-1}$ during 1992), and was also perceptible on whole tree xylem sap flux densities which displayed a 25\% decrease in 1993 compared to 1992 on the same trees (Bréda et al, 1995a).

The relationship between $g_{\mathrm{s}}$ and soil water potential at increasing depths was much tighter. A second order polynome could be fit with soil water potential as examplified in figure 3 . Such a significant regression could be established at all depths, but

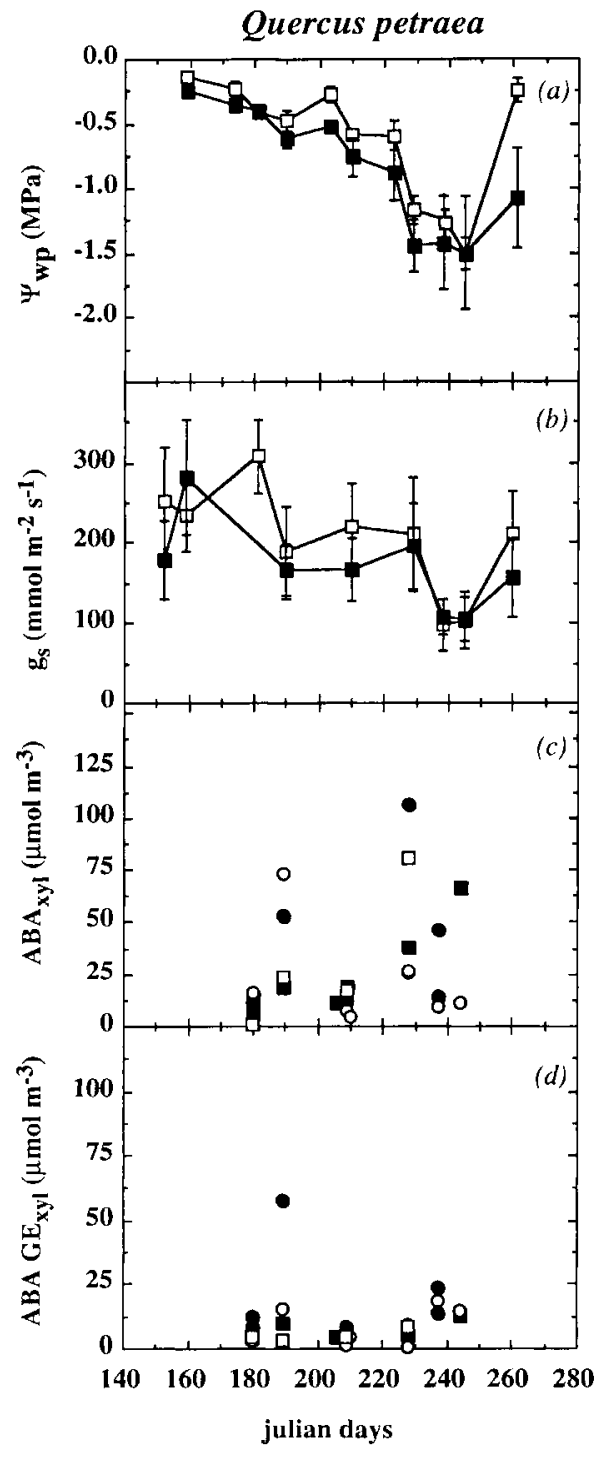

Fig 2. Seasonal time course of (a) predawn leaf water potential $\left(\Psi_{\mathrm{wp}}\right)$, (b) stomatal conductance $\left(g_{\mathrm{s}}\right)$, (c) ABA content in the xylem sap $\left(\mathrm{ABA}_{\mathrm{xy}}\right)$, and (d) ABA-GE content in the xylem sap (ABA$\left.G E_{x y l}\right)$ as recorded on adult trees of Quercus petraea submitted to an imposed drought during summer 1993. Closed symbols: water-stressed trees; open symbols: controls. Two trees were used per treatment. Mean \pm standard deviation. 


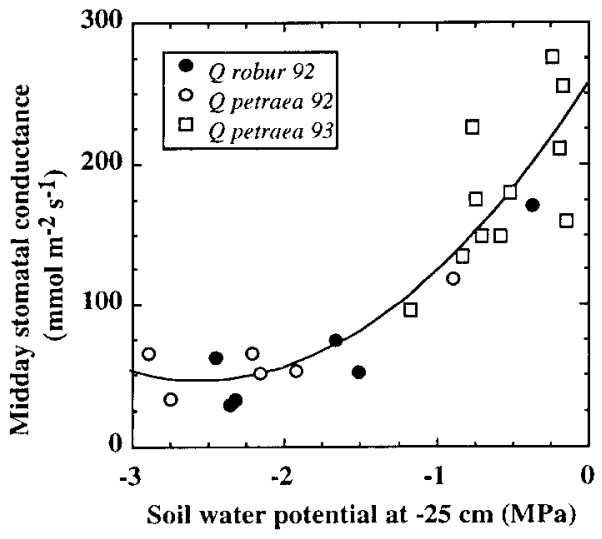

Fig 3. Relationship between midday stomatal conductance (mean of ten measurements per tree) as recorded on adult trees of $Q$ petraea and $Q$ robur and the soil water potential recorded at $25 \mathrm{~cm}$ depth in close vicinity to the trees, during the gradual onset of drought in summers 1992 and 1993. $g_{\mathrm{s}}=254.77+16.4$

$\Psi_{\mathrm{SO} 125}+32.314 \Psi_{\mathrm{SO} 125} ; r^{2}=0.842$.

the best fit with the highest regression coefficient was obtained with the soil water potential at $25 \mathrm{~cm}$ (table I).

\section{ABA concentration of xylem sap}

The amount of sap extracted from the twigs and its $A B A$ content $\left(A_{B A}\right)$ displayed $a$ high variability. In order to search for potential artefacts due to the extraction procedure, we checked for correlations between these two variables and the drought intensity (expressed as the predawn leaf water potential, $\left.\Psi_{w p}\right)$. In fact, we found no relation between $\Psi_{w p}$ and the volume of extracted $\operatorname{sap}\left(Q_{\text {ext; }}\right.$ table II), but a statistically significant one between $Q_{e x t}$ and $A B A_{x y l}$ (table II; fig 4), with a decrease of $A B A_{x y l}$ at increasing $Q_{\text {ext }}$.

$A_{B A} A_{x y l}$ displayed no self-evident seasonal time course in $Q$ petraea or in $Q$ robur regardless of drought treatment or year (fig $1 \mathrm{e}, \mathrm{f}$, and fig $2 \mathrm{c}$ ). No species related differences were detected: $\mathrm{ABA}_{\mathrm{xyl}}$ was $65.4 \pm$ 14.4 and $53 \pm 29.4 \mu \mathrm{mol} \mathrm{m}^{-3}$ in well-watered $Q$ petraea and $Q$ robur during $1992(n=5)$, and $33.2 \pm 7.8$ in well-watered $Q$ petraea during $1993(n=22)$. The differences between well-watered trees ( $\Psi_{\text {wp }}$ above -0.6 $\mathrm{MPa}$ ) and those submitted to the most severe stress $\left(\Psi_{w p}\right.$ below $\left.-1.5 \mathrm{MPa}\right)$ were not significant $(+60 \%$; table III).

The concentration of the conjugate ABAglucose ester in the xylem sap (ABA-GE $\mathrm{xyl}_{\mathrm{x}}$ ) were of the same order of magnitude and significantly correlated to $\mathrm{ABA}_{\mathrm{xyl}}\left(\mathrm{ABA}-\mathrm{GE}_{\mathrm{xyl}}\right.$ $\left.=0.856+12.9, r^{2}=0.206, n=41\right)$. As for $\mathrm{ABA}_{\mathrm{xyl}}$, no seasonal trend (figs 1 and 2) and no drought-related increase (table III) could be detected. A 100-fold difference occurred nevertheless between $1992(152 \pm 66 \mu \mathrm{mol}$

Table I. Regression coefficients between midday stomatal conductance $\left(g_{\mathrm{S}}\right.$, mean of ten values per tree) recorded in the crown of two $Q$ robur (during 1992) and two $Q$ petraea (during 1992 and 1993), and the soil water potential $\left(\Psi_{s}\right)$ recorded in the direct vicinity of each tree with psychrometers at different depths in the soil $\left(g_{\mathrm{s}}=a+b \Psi_{\mathrm{s}}+c^{4} \psi_{\mathrm{s}}{ }^{2}\right.$, correlation coefficient $\left.r^{2}\right)$.

Depth in the soil $(\mathrm{cm})$

$-25$

$-50$

$-80$

$-110$

$-140$ a

b

164

124

120

81.6

202

$\begin{array}{cc}255 & 164 \\ 259 & 124 \\ 240 & 120 \\ 219 & 81.6 \\ 242 & 202\end{array}$

c

$\mathrm{r}^{2}$ 
$\left.\mathrm{m}^{-3}\right)$ and $1993\left(9.9 \pm 4.1 \mathrm{\mu mol} \mathrm{m}^{-3}\right)$ in wellwatered trees, for which no convincing explanation could be found.

In order to test for the relationship between drought intensity and both $A B A_{x y l}$ and $A B A-G E_{x y l}$, we related them to $\Psi_{w p}$ (fig 5 for $\left.A B A_{x y l}\right)$. No correlation was found between $\Psi_{w p}$ and $A B A_{x y l}$ or $A B A-G E_{x y l}$. Table III shows the correlation coefficients obtained: none was significant. As a consequence, the observed decreases in stomatal conductance could not be related to increases in $A B A_{x y l}$ nor in total $(A B A+A B A-$
$\mathrm{GE})_{\mathrm{xyl}}$ : all correlation coefficients were not significant (table III).

\section{DISCUSSION}

Many published results indicate a direct relationship between soil moisture and stomatal conductance, independently from leaf water status (Gollan et al, 1986, and review by Davies and Zhang, 1991). This evidence has been obtained with potted plants, either using root pressurisation (Gollan et al, 1992;

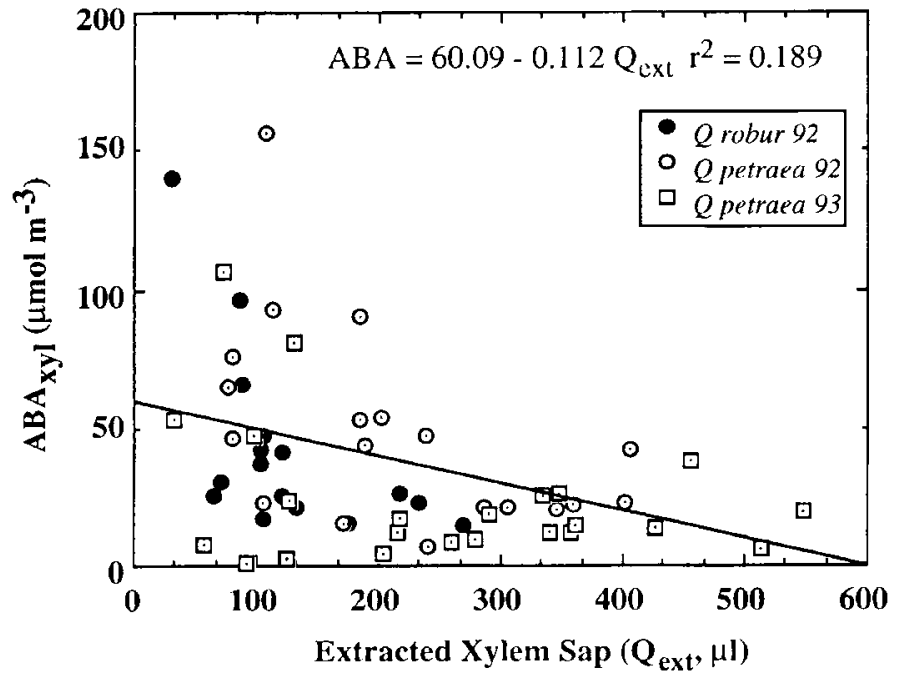

Fig 4. Relationship between volume and $A B A$ content of xylem sap extracted $\left(Q_{\text {ext }}\right)$ with a pressure chamber on twigs from adult $Q$ robur and $Q$ petraea. Each point represents an individual extraction.

Table II. Correlation coefficients $\left(r^{2}\right)$ between predawn leaf water potential $\left(\Psi_{w p}\right)$, ABA and ABA-GE concentrations in the xylem sap, and midday stomatal conductance $\left(g_{\mathrm{s}}\right)$ as measured on adult oaks $(Q$ petraea and $Q$ robur) in a stand at Champenoux during 1992 and 1993.

\begin{tabular}{|c|c|c|c|c|c|c|c|}
\hline & $v o l / A B A$ & $\Psi_{w p} / v o l$ & $\Psi_{w p} / A B A$ & $\Psi_{w p} / A B A-G E$ & $\Psi_{w p} / g_{s}$ & $A B A / \mathrm{g}_{s}$ & $(A B A+A B A-G E) / g_{S}$ \\
\hline Total data & $0.19^{\star \star}$ & 0.004 & 0.048 & 0.026 & $0.508^{\star \star}$ & 0.053 & 0.026 \\
\hline Q robur 92 & $0.34^{\star}$ & 0.001 & 0.001 & & $0.638^{\star \star}$ & 0.007 & \\
\hline$Q$ petraea 92 & 0.28 & 0.030 & 0.007 & 0.051 & $0.655^{\star \star}$ & 0.001 & 0.0150 \\
\hline$Q$ petraea 93 & 0.115 & 0.001 & 0.132 & 0.015 & $0.445^{\star \star}$ & 0.137 & 0.015 \\
\hline
\end{tabular}

\footnotetext{
${ }^{\star *}$ Significant at $0.01 ;{ }^{*}$ significant at 0.05 . Each tree was considered as a replicate
} 
Schurr et al, 1992), or split-root devices (Khalil and Grace, 1993), and was used as an evidence for the occurrence of chemical root-shoot signalling as a control mechanism for stomatal conductance.

It is less easy to demonstrate a direct control of stomata by soil moisture in field grown plants. The relative independence between midday stomatal conductance and midday leaf water potential has been well established in oaks, and a better relationship was demonstrated with predawn leaf water potential ( $\Psi_{\mathrm{wp}}$, Bréda et al, 1993a, and our results). Nevertheless, this relationship always exhibited a nonlinear shape (Bréda et al, 1993a,b; Epron et al, 1993), with steep decreases of stomatal conductance at high $\Psi_{w p}$, and more gradual ones for lower values. Moreover, the relationship among $\Psi_{\text {wp }}$ and $g_{\mathrm{S}}$ exhibited climate-related shifts: during 1993, where vapour pressure deficits in the air were lower than in 1992, $g_{\mathrm{S}}$ was much higher for any given $Y_{w p}$.

Bréda et al (1995b) demonstrated that $\Psi_{\mathrm{wp}}$ in the oak trees studied here was close to the soil water potential of the deepest rooted soil layers, and that substantial decreases in water potential could already occur in the upper layers without any noticeable effect on $\Psi_{\text {wp }}$, but with already significant stomatal closure. Much closer relationships, with less curvilinearity, could also be established here between $g_{\mathrm{s}}$ and soil water potentials at different depths. The best fit was obtained with values measured at $-25 \mathrm{~cm}$, where the rooting density was highest and the water depletion fastest: this may be used as an argument for a control of stomatal conductance by the water availability in the upper soil layers, and not by bulk water reserves. However, care should be taken that in a soil during drought, all layers dry out gradually even if not at the same pace, and that therefore all parameters describing soil water in the different horizons are more or less correlated. Furthermore, diurnal variations in stomatal conductance still occur at any given soil moisture content, with midday closure depending on the actual vapour pressure deficit and other factors: this was demonstrated on the
Fig 5. Relationship between predawn leaf water potential and $(\mathbf{a}, \mathbf{b})$ stomatal conductance $\left(g_{\mathrm{s}}\right)$, and (c, d) ABA content in the xylem $\operatorname{sap}\left(A B A_{x y l}\right)$ of adult oak trees as recorded during 1992 on $Q$ petraea and $Q$ robur, and during 1993 on $Q$ petraea submitted or not to soil water depletion.

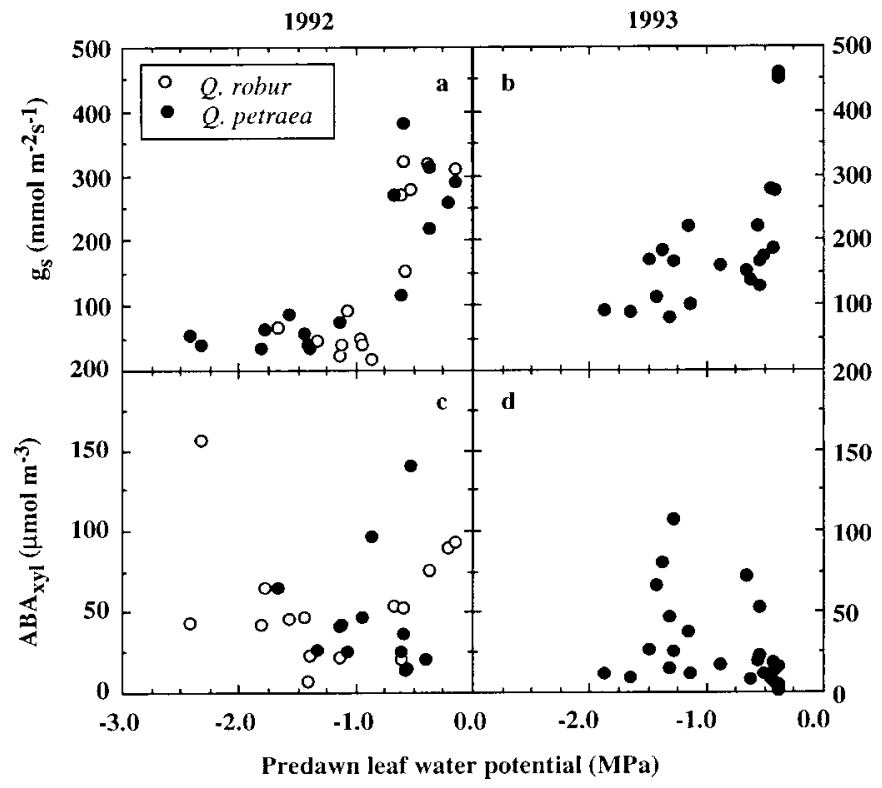


Table III. Mean values ( \pm SE) of ABA and ABA-GE concentrations in the xylem sap, and of midday stomatal conductance $\left(g_{\mathrm{s}}\right.$, mean of ten replicates for each single tree) of well-watered versus severely waterstressed oak trees in a natural stand at Champenoux.

Well watered $\mathrm{n} \quad$ Stressed $\mathrm{n} \quad$ Significance

$\begin{array}{lccccc}\begin{array}{l}\mathrm{ABA} \mathrm{xyl}_{\mathrm{xl}} \\ (\mu \mathrm{mol} \mathrm{m})^{-3}\end{array} & 33.2 \pm 7.8 & 22 & 51.8 \pm 14.7 & 9 & \text { NS } \\ \begin{array}{l}\mathrm{ABA}-\mathrm{GE}(1992) \\ \left.(\mu \mathrm{mol} \mathrm{m})^{-3}\right)\end{array} & 152 \pm 32.9 & 4 & 132 \pm 43.9 & 5 & \mathrm{NS} \\ \begin{array}{l}\mathrm{ABA}-\mathrm{GE}(1993) \\ \left.(\mu \mathrm{mol} \mathrm{m})^{-3}\right)\end{array} & 9.92 \pm 4.05 & 13 & 16.7 \pm 1.85 & 2 & \mathrm{NS} \\ \begin{array}{l}g_{\mathrm{s}} \\ \left(\mathrm{mmol} \mathrm{m}^{-2} \mathrm{~s}^{-1}\right)\end{array} & 289.3 \pm 20.7 & 23 & 77.3 \pm 13.4 & 9 & \end{array}$

Values from trees with predawn leaf water potential above $-0.6 \mathrm{MPa}$ (well-watered) and below $-1.5 \mathrm{MPa}$ (stressed) were used. Values of $A B A_{k y l}$ for $Q$ robur and $Q$ petraea and for 1992 and 1993 were pooled together because of lack of differences. Values for ABA-GE were from $Q$ petraea and both years were distinguished. NS: not significant.

oak trees used here (Epron et al, 1992) as well as for many other species (Tenhunen et al, 1984). Stomatal aperture of trees in the field is far from being exclusively controlled by soil moisture.

An alternative hypothesis to consider is the one underlining the fine tuning of stomatal conductance to leaf water potential in a feedforward regulation aimed at maintaining it close to, but slightly above, the cavitation threshold (Jones and Sutherland, 1991). Bréda et al (1993a) and Cochard et al (1996) showed that stomata of the tested oak trees were almost completely closed when embolism began to develop, and that a good relationship could be found between stomatal control of transpiration and the total, soil-to-leaf hydraulic conductance of oak trees. The physiological mechanisms relating hydraulic conductance and stomatal conductance are still a matter of discussion, and it may also be stated that stomatal control and vulnerability to cavitation could be co-evolved traits.
The ability of ABA to induce stomatal closure is generally accepted (eg, Harris and Outlaw, 1991, and reviews by Hartung and Slovik, 1991 and Davies et al, 1994). ABA receptors are thought to be localized at the outer membrane of guard cells, but they remain to be precisely identified (Anderson et al, 1994). It is also clear that drought induces a remobilisation of existing ABA poois transported to guard cells, rather than a de novo synthesis, which occurs only during strong stress when stomata are already closed (Hartung and Slovik, 1991). The origin of this ABA is still a matter of debate. A model based on the known physicochemical properties of ABA ( $\mathrm{pKa}$, permeability, turnover rate, etc) developed by Hartung and Slovik (1991) showed that a pH drift in the apoplast could induce remobilisation of chloroplastic pools of ABA, and an efflux into the leaf apoplast resulting in stomatal closure. Increases in apoplastic ABA (ie, in sap extracted with a pressure chamber directly from leaves) have been evidenced 
by Harris and Outlaw (1991) and Correia and Pereira (1994) among many others.

Nevertheless, the question whether rootissued $A B A$ is involved in this control of stomatal conductance remains open. The presence of $A B A$ (and ABA-GE) in the xylem sap of plants, including trees, has been firmly established. Values around 60 (Prunus armeniaca, Loveys et al, 1987), 100 (Prunus dulcis, Wartinger et al, 1990; Acer saccharum, Bertrand et al, 1994), 100-250 (seedlings of Quercus petraea, $Q$ robur, $Q$ pubescens, Scuiller, 1990) and up to $500 \mu \mathrm{mol} \mathrm{m} \mathrm{m}^{-3}$ (Quercus agrifolia, Hartung and Slovik, 1991) have been reported, and are of the same order of magnitude as the 30 and $50 \mu \mathrm{mol} \mathrm{m} \mathrm{m}^{-3}$, respectively, for ABA and ABA-GE we detected in Quercus robur and $Q$ petraea. Unfortunately, this consensus does not hold for droughtinduced increases: the just cited authors frequently observed a three- to ten-fold increase during drought. This was not the case in our trees; the slight increase detected for the most severe stress intensities $(+50 \%)$ was statistically not significant and, in any case, remained much below the previous range.

Many hypotheses may be invoked to explain the lack of increase in $\mathrm{ABA}_{\mathrm{xyl}}$ during our experiments as compared to other reports. Numerous artefacts may arise during xylem sap extraction, and induce either decreases or increases in $\mathrm{ABA}_{\mathrm{xyl}}$. A dilution by symplasmic water may occur during overpressurisation of the leafy shoot, and could possibly explain the negative correlation we found between the volume of extracted sap and $A_{B A_{x y}}$. Nevertheless, this correlation explained only a weak fraction of the variability, and furthermore, the amount of extracted sap was independent of the stress intensity (as estimated by $\Psi_{\text {wp }}$ ). Its incidence on the lack of difference between stressed and nonstressed trees was probably minor. A pollution of xylem sap by phloem ABA may frequently pro- mote increases in the apparent value of $A B A_{x y l}$ (Else et al, 1994), but removal of the bark before extraction minimized the risk. Finally, a mixture of xylem sap with apoplastic sap originating from the leaves (the latter being potentially enriched with ABA mobilised from the intracellular pools) may occur when sap is directly extracted from leaf petioles. The impact of this artefact was probably only minor in our case, due to the length of the stem of the twigs used. Despite the potential importance of such artefacts, they cannot alone explain the lack of drought-induced increase of $\mathrm{ABA}_{\mathrm{xy}}$ in our measurements.

The lack of increase in $A_{B A}$ in response to drought cannot either be analysed as a specific feature of oaks. Several works evidenced increased $\mathrm{ABA}_{\mathrm{xyl}}$ in oak seedlings (Scuiller, 1990; Stiller, 1995; Pallardy, personal communication). Two other factors could help explain it: the size of the trees and the slow installation of the stress. Besides the study of Wartinger et al (1990), all other reports used seedlings as plant material, and did impose drought rather rapidly (several days). In the case of tall trees submitted to a gradual soil water depletion, the question of relative contributions of root-issued and leaf-issued ABA to the control of stomatal conductance arises. Several facts show that the link between $\mathrm{ABA}_{\mathrm{xyl}}$ may not be as strong as sometimes argued. Stomatal closure preceded the increase in $\mathrm{ABA}_{\mathrm{xyl}}$ in Phaseolus (Trejo and Davies, 1991). Moreover, important changes in the relationships between $A B A_{x y l}$ and stomatal conductance have been detected and ascribed to changes in the apparent sensitivity of stomata to $\mathrm{ABA}_{\mathrm{xyl}}$ (Schurr et al, 1992; Tardieu and Davies, 1992) and related to reductions in leaf water potential (Tardieu and Davies, 1993). They might be of importance during gradually increasing and long-lasting drought stress, together with more subtle changes in xylem sap properties (Gollan et al, 1992), and could induce 
changes in the balance between ABA issued from the roots or from intracellular leaf compartments.

Moreover, a high rate of sequestration followed by catabolisation of apoplastic ABA has been evidenced (Hartung and Slovik 1991); values to half-life time as low as 30 min have sometimes been reported (Prunus, Gowing et al, 1993). As a consequence, it may be argued that the factor controlling stomatal aperture may be closer to the total flux of ABA into leaves rather than to the concentration in xylem sap alone (Gowing et al, 1993a). We estimated the total amount of $A B A$ transported to the crowns from $A B A_{x y l}$ and from measured total sap fluxes (Bréda et al, 1993a). As a consequence of the limited differences in $\mathrm{ABA}_{\mathrm{xyl}}$ between controls and stressed trees, and of the severe reduction in total sap fluxes (Bréda et al, 1993b), the total flux of $A B A$, varying between 20 and $600 \mathrm{nmol}$ tree $e^{-1} d^{-1}$, was highest in the well-watered and actively transpiring individuals. Similar results were reported by Jackson et al (1995) with saplings of Picea sitchensis and Pinus sylvestris. Despite an 11-fold increase in $\mathrm{ABA}_{\mathrm{xyl}}$ in response to drought, the total flux of $A B A$ to the needles was of the same order of magnitude in stressed and in wellwatered plants. The active concentration in the vicinity of stomatal guard cells would therefore have been lower in stressed oak trees if root-issued $A B A$ was the unique source of $A B A$ acting on stomata.

Finally, we may state, according to the work of Hartung and Slovik (1991) and to recent data published by Trejo et al (1993), that the analysis of drought-induced and ABA-mediated stomatal closure has to take into account changes in the compartmentation of ABA both in leaves and in roots, transport from roots to leaves in the xylem sap, and from leaves to roots in the phloem, and finally the turnover rate of $A B A$ in the apoplastic solution in the vicinity of the guard cells.

\section{CONCLUSION}

The drought imposed on oak trees did not result in detectable increases of concentration of $A B A$ in the xylem sap. This may not necessarily be an argument for the lack of root control of stomatal aperture in tall trees, nor for the absence of root-issued ABA and its importance as drought signal, but stresses the need for additional research integrating all aspects of ABA transport in water-stressed plants.

\section{ACKNOWLEDGMENTS}

Support for this study was brought by an EEC Research Programme ("Water stress, xylem dysfunctions and dieback mechanisms in European oaks", STEP CT 0090-50), and by EUROSILVAEUREKA 447 ("Root to shoot communications in forest trees: signals for decreasing soil moisture"). The skillful help of JM Gioria, JM Desjeunes and A Pillot for sap extraction is gratefully acknowledged. The experimental plot at Champenoux was managed by A Granier, and the scaffolding towers allowing access to crowns were built by $F$ Willm and B Clerc. Useful comments by ED Schulze, S Pallardy and F Tardieu and two anonymous reviewers on an earlier version of this paper are gratefully acknowledged.

\section{REFERENCES}

Anderson BE, Ward JM, Schroeder JI (1994) Evidence for an extracellular reception site of abscisic acid in Commelina guard cells. Plant Physiol 104, 1177 1183

Bertrand A, Robitaille G, Nadeau P, Boutin R (1994) Effects of soil freezing and drought stress on abscisic acid content of sugar maple sap and leaves. Tree Physiol 14, 413-426

Bréda N, Cochard H, Dreyer E, Granier A (1993a) Field comparison of transpiration, stomatal conductance and vulnerability to cavitation of Quercus petraea and Quercus robur under water stress. Ann Sci For $50,571-582$

Bréda N, Cochard H, Dreyer E, Granier A (1993b) Seasonal evolution of water transfer in a mature oak stand (Quercus petraea: seasonal evolution and 
effects of a severe drought. Can J For Res 23, 11361143

Bréda N, Granier A, Aussenac G (1995a) Effects of thinning on soil water balance and tree water relations, transpiration and growth in an oak forest (Quercus petraea). Tree Physiol 15, 295-306

Bréda N, Granier A, Barataud F, Moyne C (1995b) Soil water dynamics in an oak stand. I. Soil moisture, water potentials and root water uptake. Plant Soil (in press)

Cochard H, Bréda N, Granier A, Aussenac G (1992) Vulnerability to air embolism and hydraulic architecture of three European oak species (Quercus petraea (Matt) Liebl, $Q$ pubescens Willd, $Q$ robur $L$ ). Ann Sci For 49, 225-233

Cochard H, Bréda N, Granier A (1996) Whole tree hydraulic conductance and water loss regulation in Quercus during drought: evidence for stomatal control of embolism. Ann Sci For 53, 197-206

Correia MJ, Pereira JS (1994) Abscisic acid in apoplastic sap can account for the restriction in leaf conductance of white lupins during moderate soil drying and after rewatering. Plant Cell Environ 17, 845-852

Davies WJ, Zhang J (1991) Root signals and the regulation of growth and development of plants in drying soil. Ann Rev Plant Physiol Plant Mol Biol 42, 55-76

Davies WJ, Tardieu F, Trejo CL (1994) How do chemical signals work in plants that grow in drying soils? Plant Physiol 104, 309-314

Else MA, Davies WJ, Whitford PN, Hall KC, Jackson MB (1994) Concentrations of abscisic acid and other solutes in xylem sap from root systems of tomato and castor-oil plants are distorted by wounding and variable sap flow rates. J Exp Bot 45, 317-323

Epron D, Dreyer $E$ (1993) Compared effects of drought on photosynthesis of adult oak trees (Quercus petraea [Matt] Liebl and Quercus robur L) in a natural stand. New Phytol 125, 381-389

Epron D, Dreyer E, Bréda N (1992) Photosynthesis of oak trees (Quercus petraea (Matt) Liebl) during drought under field conditions: diumal evolution of net $\mathrm{CO}_{2}$ assimilation and photochemical efficiency of photosystem II. Plant Cell Environ 15, 809-820

Gollan T, Passioura J, Munns R (1986) Soil water status affects the stomatal conductance of fully turgid wheat and sunflower leaves. Aust J Plant Physiol 13, 459464

Gollan T, Schurr U, Schulze ED (1992) Stomatal response to drying soil in relation to changes in the xylem sap composition of Helianthus annuus. I. The concentration of cations, anions, amino acids in, and $\mathrm{pH}$ of the xylem sap. Plant Cell Environ 15, 551-559

Gowing DJG, Jones HG, Davies WJ (1993) Xylem-transported abscisic acid - the relative importance of its mass and its concentration in the control of stomatal aperture. Plant Cell Environ 16, 453-459
Harris MJ, Outlaw WH (1991) Rapid adjustment of guardcell abscisic acid levels to current leaf-water status. Plant Physiol 95, 171-173

Hartung W. Slovik S (1991) Physicochemical properties of plant growth regulators and plant tissues determine their distribution and redistribution: stomatal regulation by abscisic acid in leaves. New Phytol $119,361-382$

Jackson GE, Irvine J, Grace J, Khalil AM (1995) Abscisic acid concentrations and fluxes in droughted conifer saplings. Plant Cell Environ 18, 13-22

Jones HG, Sutherland RA (1991) Stomatal control of xylem embolism. Plant Cell Environ 14, 607-612

Khalil AM, Grace J (1993) Does xylem sap ABA control the stomatal behaviour of water stressed sycamore (Acer pseudoplatanus L) seedlings? J Exp Bot 44, 1127-1134

Label P, Imbault N, Villar M (1994) ELISA quantitation and GC-MS identification of abscisic acid in stigma, ovary and pedicel of pollinated poplar flowers ( $P$ Opulus nigra L). Tree Physiol 14, 521-530

Landmann G, Becker M, Delatour C, Dreyer E, Dupouey JL (1993) Oak dieback in France: historical and recent records, possible causes, current investigations. Rungespräche der Kommission für Ökologie, "Zustand und Gefährdung des Laubwälder" 5, 97-114

Loveys BR, Robinson SP, Downton WJS (1987) Seasonal and diurnal changes in abscisic acid and water relations of apricot leaves (Prunus armeniaca $\mathrm{L}$ ). New Phytol 107, 15-27

Schurr U, Gollan T, Schulze ED (1992) Stomatal response to drying soil in relation to changes in the xylem sap composition of Helianthus annuus. II. Stomatal sensitivity to abscisic acid imported from the xylem sap. Plant Cell Environ 15, 561-567

Scuiller I (1990) Exploration de la variabilité des comportements écophysiologiques de semis de chênes blancs européens soumis à la sécheresse. Thèse de l'Université de Nancy I, France

Stiller V (1995) Einfluss der Stickstoffernaehrung auf Wachstum und Gaswechsel von Stieleichen (Quercus robur L) bei Bodentrockenheit. PhD Dissertation, University of Bayreuth, Germany

Tardieu F, Davies WJ (1992) Stomatal response to abscisic acid is a function of current plant water status. Plant Physiol 98, 540-545

Tardieu F, Davies WJ (1993) Integration of hydraulic and chemical signalling in the control of stomatal conductance and water status of droughted plants. Plant Cell Environ 16, 341-349

Tardieu F, Zhang J, Katerji N, Bethenod O, Palmer S, Davies WJ (1992) Xylem ABA controls the stomatal conductance of field grown maize subjected to soil compaction or soil drying. Plant Cell Environ 16 , $413-420$

Tenhunen JD, Lange OL, Gebel J, Beyschlag W, Weber JA (1984) Changes in the photosynthetic capacity, 
carboxylation efficiency and $\mathrm{CO}_{2}$ compensation point associated with midday stomatal closure and midday depression of net $\mathrm{CO}_{2}$ exchange of leaves of Quercus suber. Planta 162, 193-203

Trejo CL, Davies WJ (1991) Drought-induced closure of Phaseolus vulgaris stomata precedes leaf water deficit and any increase in xylem ABA concentration. J Exp Bot 42, 1507-1516
Trejo CL, Davies WJ, Ruiz LMP (1993) Sensitivity of stomata to ABA: an effect of the mesophyll. Plant Physiol 102, 497-502

Wartinger A, Heilmeier $H$, Hartung W, Schulze ED (1990) Daily and seasonal courses of leaf conductance and abscisic acid in the xylem sap of almond trees (Prunus dulcis (Miller) DA Webb) under desert conditions. New Phytol 116, 581-587 